\title{
A América Latina em disputa: História e historiografia de uma polêmica ${ }^{1}$
}

\author{
Valdir Donizete dos Santos Junior ${ }^{2}$
}

\begin{abstract}
Resumo: Este artigo tem por objetivo discutir aspectos relacionados à circulação e aos significados da ideia de "América Latina". Partindo de um debate iniciado na década de 1960 por autores como o norte-americano John Leddy Phelan e o uruguaio Arturo Ardao, este texto busca compreender as concepções historiográficas que têm balizado as discussões acerca dessa temática. Da mesma forma, procura compreender em perspectiva histórica a construção e as diversas apropriações dessa denominação, tanto como artefato de projetos imperiais, quanto como instrumento de defesa identitária e geopolítica dos países hispano-americanos em relação às pretensões expansionistas dos Estados Unidos. Este texto se debruça, portanto, por um lado, sobre produções intelectuais relativamente mais recentes que elaboraram uma interpretação sobre as "origens" do conceito de América Latina; e, por outro, sobre aquelas, particularmente francesas e hispanoamericanas, que participaram desse processo no século XIX, enfatizando a utilização da ideia de "latinidade" como forma de se posicionar contra a presença norte-americana na América Central.
\end{abstract}

Palavras-chaves: Amérca Latina; História; Historiografia

\section{Latin America in disupute: History and historiography of a controversy}

\begin{abstract}
This article aims at discussing aspects related to the circulation and the meanings of the idea of "Latin America". Starting from a debate initiated34 $\mathrm{m}$ in the 1960s by authors such as the American John Leddy Phelan and the Uruguayan Arturo Ardao, this text seeks to understand the historiographical concepts that have guided the discussions on this theme. Likewise, it seeks to understand in historical perspective the construction and the various appropriations of this denomination, both as an artifact of imperial projects and as an instrument of identity and geopolitical defense of the Hispanic American countries in relation to the expansionist pretensions of the United States. Therefore, this text focuses, on the one hand, on relatively more recent intellectual productions that elaborated an interpretation on the "origins" of the concept of Latin America; and, on the other, about those, particularly French and Hispanic-Americans, who participated in this process in the 19th century, emphasizing the use of the idea of

\footnotetext{
${ }^{1}$ O título é uma homenagem ao clássico de GERBI (1993)

${ }^{2}$ Professor de Ensino Básico, Técnico e Tecnológico do Instituto Federal de São Paulo (IFSPCampus Jacareí). Doutor em História Social na Faculdade de Filosofia, Letras e Ciências Humanas da Universidade de São Paulo (FFLCH-USP). Contato: valdir.santos@ifsp.edu.br.
} 
"Latinity" as a way to position themselves against the American presence in Central America.

Keywords: Latin America; History; Historiography

Artigo recebido em: 21/02/2020

Artigo aprovado para publicação em: 19/06/2020

\section{Introdução}

Desde as independências em relação às metrópoles ibéricas, no início do século XIX, dentre os diversos impasses que se afiguravam aos atores dos processos de formação dos Estados nacionais nas Américas, a construção das identidades dos novos países se apresentava como uma questão primordial. Nesse contexto, reescrever a história, ordenar o presente e projetar o futuro tornaram-se imperativos para justificar a existência de unidades politicamente autônomas que buscavam reconhecimento internacional e legitimação interna (PRADO, 2008).

$\mathrm{Na}$ perspectiva das novas elites nacionais, quando rompidos os laços com os colonizadores europeus, não se podia mais ser somente um espanhol ou português no Novo Mundo, mas sim um membro de uma nova "comunidade imaginada" com suas próprias características políticas, sociais e culturais (ANDERSON, 2008). Na perspectiva dos setores populares - bastante diversa em escala continental, composta, de modo geral, por indígenas, africanos, afrodescendentes escravizados e libertos e homens e mulheres livres pobres, muitas vezes mestiços - as independências e os novos países tornaram-se signos de esperança e, na maioria das vezes, de decepção. Excluídos ou representados de modo idealizado ou subalterno no processo de construção das novas identidades nacionais, tais grupos não deixaram, ao longo do tempo, de constituir suas próprias concepções identitárias nem sempre coincidentes com as narrativas oficiais.

É preciso destacar, entretanto, que além dos diversos projetos pautados na construção das identidades nacionais nas Américas, também começaram a se desenhar, em meados do século XIX, os primeiros esboços de uma identidade mais geral que poderia ser chamada aqui de subcontinental e, mais especificamente, em consonância com os objetivos deste artigo, latino-americana. Ressalte-se que, como em todo processo dessa 
natureza, as identidades se constituem intrinsecamente associadas às alteridades (PRADO, 2008). Pode-se dizer, nesse sentido, que a definição e a afirmação do que é próprio e particular a indivíduos, a grupos sociais, étnicos ou às nações, estabelece-se necessariamente em relação a um "outro" também "imaginado" caracterizado como diverso ou antagônico, que, além disso, frequentemente se apresenta como perigoso e ameaçador.

Se nos processos de emancipação política dos países latino-americanos, o “outro" dos recém-criados Estados nacionais eram as metrópoles europeias, não demorou para um novo rival se apresentar como o antagonista privilegiado nas relações com o subcontinente e, mais particularmente, com a América Hispânica: os Estados Unidos. Nesse sentido, a elaboração do conceito de "América Latina", anunciada e ensaiada ao menos desde a década de 1830, mas enunciada somente a partir da década de 1850, deve ser compreendida, primeiramente, à luz das conexões, ao mesmo tempo, dicotômicas e dialéticas entre os países de colonização ibérica e a república anglo-saxônica.

Restringir, entretanto, a história desse conceito ${ }^{3}$ unicamente às correlações internas do continente americano é simplificar o processo. A definição da existência de uma América "latina" é fruto também de uma intensa trama pautada na circulação de ideias entre o Velho e o Novo Mundo e associa-se, não obstante, a interesses geopolíticos da França que, embora estivessem presentes na retórica dos letrados daquele país desde o início do século XIX, se intensificaram com a ascensão ao poder de Luís Bonaparte em 1848 e, mais especificamente, a partir do golpe de Estado que, em 1851, o fez ditador e posteriormente imperador sob o título de Napoleão III.

Na lógica da circulação das ideias, é nesse intrincado jogo entre a identidade subcontinental, a alteridade em relação aos Estados Unidos e as projeções e os interesses

\footnotetext{
${ }^{3}$ É preciso ressaltar que, embora, por vezes, o termo "conceito" possa surgir, em meio ao texto, em referência à formulação do nome "América Latina", este artigo não é um trabalho de "história dos conceitos" em termos estritos. A despeito de inspirarem algumas das reflexões deste texto, nos trabalhos produzidos por tais vertentes há um protagonismo dos aspectos linguísticos que não temos por objetivo alcançar aqui. A discussão proposta nas páginas seguintes se insere no âmbito da circulação das ideias e da construção de identidades em diálogo com com uma história política e cultural em perspectiva transatlântica (PRADO, 2008; SOARES, 2017). Sobre a História dos Conceitos, ver JASMIN \& FERES (2006).
} 
franceses que o conceito de "América Latina" deve ser compreendido. Embora vários textos já tenham tratado dessa questão, este artigo pretende fornecer novos elementos para a discussão, promovendo um balanço sobre o que já foi escrito sobre o tema e tratando de fontes até aqui ainda pouco analisadas entre os que buscaram participar desse debate.

Em primeiro lugar, pretende-se aqui destacar o papel fundamental ocupado nesse processo pela América Central, enfatizando as disputas internacionais que visavam à construção de um canal que facilitasse a conexão entre os oceanos Atlântico e Pacífico em meados do século XIX. Nesse contexto, o Panamá e a Nicarágua se constituíram como os espaços que mais conviveram com a presença frequentemente agressiva dos Estados Unidos ao longo da década de 1850. A elaboração do conceito de "América Latina" não pode ser compreendida, nesse sentido, sem uma percepção mais aprofundada acerca das disputas geopolíticas que vinham sendo travadas nessa região entre hispano-americanos, norte-americanos e europeus.

Além disso, este artigo procura também trazer para o centro do debate um personagem um tanto obscuro que teria contribuído de forma relevante para a invenção do conceito de "América Latina": o francês Felix Belly (1816-1886). Jornalista bonapartista que cobriu a Guerra da Crimeia (1853-1856), voltou sua atenção após esse conflito à elaboração de um projeto que visava à construção de um canal interoceânico na América Central. Belly instrumentalizou, em 1856, o termo “América Latina” pouco tempo antes de sua utilização, no mesmo ano, por autores como o colombiano José Maria Torres Caicedo ou o chileno Francisco Bilbao.

Dessa forma, com o objetivo de discutir as dinâmicas da circulação das ideias entre hispano-americanos e europeus, busca-se neste artigo compreender os diálogos entre os textos coevos produzidos nos dois lados do Atlântico, as especificidades das diversas formulações identitárias e os múltiplos significados atribuídos à denominação "América Latina" em meados do século XIX. 


\section{"América Latina": origens, significados e usos na historiografia}

Desde a década de 1960, diversos intelectuais ligados às ciências humanas têm procurado discutir o conceito de "América Latina” guiados basicamente por dois grandes objetivos: desvendar suas origens e debater a validade de sua utilização.

Sobre a temática das origens, duas são as posições paradigmáticas: de um lado, aquela que compreende tal conceituação do subcontinente como criação e imposição estrangeira pautada por interesses geopolíticos externos e, de outro, a que afirma sua origem autóctone e anti-imperial resultante de uma resistência de caráter local à voracidade das grandes potências, particularmente dos norte-americanos. Entre os que se posicionam sobre a validade ou não de seu uso, alguns permanecem considerando-o uma ferramenta intelectual ou política necessária e desejável, enquanto outros entendem que seus limites são maiores que seus méritos.

A polêmica sobre o nascimento do conceito de "América Latina" remonta ao ano de 1965, quando dois textos aparentemente antagônicos sobre o tema vieram à tona. $\mathrm{O}$ primeiro deles foi "El origen de la idea de Latinoamérica", conferência ministrada pelo historiador norte-americano John Leddy Phelan, no contexto de uma homenagem ao intelectual mexicano Edmundo O'Gorman, ocorrida naquele ano na Universidade Nacional Autônoma do México (UNAM).

Nesse texto, Phelan atribuía a designação "América Latina" unicamente ao panlatinismo francês existente durante o Segundo Império (1852-1870), sob Napoleão III. Um de seus principais artífices teria sido o engenheiro e destacado economista Michel Chevalier, conselheiro de Estado do governo bonapartista, que viajara anteriormente, na década de 1830, aos Estados Unidos, ao México e a Cuba. Ao retornar ao seu país, Chevalier foi se tornando, ao longo do tempo, personagem político e intelectual de relevância, atuando como professor do Collège de France e ocupando uma cadeira no Senado. Em relação às Américas, defendeu desde a década de 1830 a construção de um canal interoceânico na América Central sob a batuta francesa e constituiu-se como um dos grandes arautos da intervenção de seu país sobre o México na década de 1860 
(SANTOS JUNIOR, 2019; WALCH, 1975). Sob a influência de Chevalier, o conceito de “América Latina” teria sido inventado, na perspectiva de Phelan, na França, em 1861, por L. M. Tisserand na Revue des races latines (PHELAN, 1993, pp. 441-455).

Partindo de outra perspectiva, merece destaque o texto do intelectual uruguaio Arturo Ardao "La idea de Latinoamérica", publicado no mesmo ano que a conferência de Phelan (ARDAO, 1965). Escrito inicialmente para o célebre semanário de Montevidéu Marcha, esse artigo constituiu-se como a base para seu trabalho posterior Génesis de la idea y el nombre América Latina, de 1980, em que desenvolveu com mais vagar as ideias veiculadas anteriormente. Se Ardao localizava na França as origens de uma concepção sobre a existência de uma "raça latina" e determinava Michel Chevalier como o primeiro a associar a América de colonização ibérica à "latinidade", afirmava, contrapondo-se ao autor norte-americano, que haviam sido, na realidade, hispano-americanos, em geral radicados na Europa, os primeiros a forjar não somente a ideia, mas o nome "América Latina".

Destacava, nesse contexto, o periodista, político, diplomata e escritor colombiano José Maria Torres Caicedo, autor do poema "Las dos Américas", que, na cidade de Veneza, em 26 de setembro de 1856, escrevera os versos: "La raza de la Améria Latina / al frente tiene la sajona raza", onde, pela primeira vez, segundo o intelectual uruguaio, teria sido utilizado o substantivo composto “América Latina”. Nessa concepção, o nome do subcontinente fora elaborado em contraponto aos Estados Unidos que, desde meados da década de 1840, vinham representando uma ameaça ao restante do Novo Mundo (ARDAO, 1980, pp. 11-95).

A despeito do enfoque excessivo das matrizes interpretativas propostas por Phelan e Ardao em definir precisamente a "origem" exata da denominação América Latina, ambas, mesmo se apresentando na maior parte das vezes como antagônicas, podem ser tomadas, não obstante, como, de certa forma, complementares. Por um lado, a ênfase de Phelan no panlatinismo francês da época de Napoleão III expõe o surgimento de um conceito repleto de interesses imperiais. Por outro, o enfoque de Ardao na 
resistência em relação aos Estados Unidos ressalta a combatividade e os usos políticos do termo como artefato de afirmação local e enfrentamento global.

Além disso, a despeito das armadilhas em que recaiu dada sua busca pelo "ídolo das origens" - para se utilizar aqui do termo de Marc Bloch (2001) - do nome "América Latina" e do manejo de uma história das ideias que parece, muitas vezes, não dialogar de maneira efetiva com a história política e social, duas importantes contribuições de Ardao merecem ser destacadas: primeiramente, a articulação, no texto do autor, de um esboço de uma história da circulação das ideias entre a França e as Américas, e, em decorrência disso, a afirmação de que as ideias não possuem um sentido de mão-única, ou seja, não são inventadas na Europa e copiadas e aderidas acriticamente na América Latina, mas, pelo contrário, têm autonomia mesmo quando em diálogo com formulações europeias.

Apropriando-se, em parte, da argumentação de Ardao, na medida em que afirmava também a primazia efetiva dos hispano-americanos na invenção do nome “América Latina", o historiador chileno Miguel Rojas Mix questionava, nesse debate, a patente de seu inventor. Embora mencionasse os usos que o também chileno Francisco Bilbao fez dos termos "raza latinoamericana" e "América latina, sajona e indígena" no discurso "Iniciativa de América", proferido em Paris, em 22 de junho de 1856, quase três meses antes do poema de Torres Caicedo vir à luz, Ardao não considerava ainda forjado o conceito, pois o termo "latina" configurava-se não como parte do substantivo composto “América Latina", mas ainda como um adjetivo complementar a "América". Mesmo afirmando que pouco importava quem teria sido o primeiro a conceitualizar a América Ibérica como "latina", Rojas Mix, contrapondo-se ao intelectual uruguaio, destacava não somente o papel pioneiro de Bilbao na formulação da nomenclatura, mas também seu americanismo combativo e engajado (ROJAS MIX, 1986, pp. 35-47).

Mais recentemente, dois livros em particular se apresentam ainda hoje, passada quase uma década e meia de sua publicação, como abordagens instigantes e originais acerca dessa temática: A história do conceito de "Latin America" nos Estados Unidos, do brasileiro João Feres Junior, e La idea de América Latina, do argentino Walter Mignolo, ambos lançados curiosamente no mesmo ano de 2005. Em seu trabalho, Feres 
Junior (2005) busca analisar as imagens construídas nos Estados Unidos sobre a América de colonização ibérica desde o século XIX até a virada para o século XXI, debatendo a formulação de estereótipos sobre a região naquele país não somente no senso comum, mas também nos meios acadêmicos. Além disso, destaca a profunda relação entre a construção do conceito e a política externa norte-americana em particular após o fim da Segunda Guerra Mundial em 1945.

Partindo de outras perspectivas teóricas, em particular dos chamados estudos decoloniais, Mignolo (2005) produziu um ensaio muito interessante, discutindo como as ideias de "América" e, posteriormente, sua derivação "América Latina" se constituíram associadas aos processos de "modernidade" e "colonialidade" que se iniciaram em escala global a partir do século XVI. Por meio de tramas bastante complexas, procurou demonstrar como, paralelamente, as denominações concebidas como expressão de um projeto de hegemonia colonial do Ocidente, inclusive dos setores dominantes iberoamericanos, puderam também ganhar novos significados por meio de discursos contrahegemônicos, em especial dos grupos subalternos da região.

Os livros de Feres Junior e Mignolo se apresentam, nesse sentido, como contribuições importantes para a compreensão acerca dessa temática, entre outras coisas, por destacarem, cada um em sua especificidade, as dimensões imperiais que cercam o conceito e a ideia de "América Latina”, seus múltiplos significados e suas reapropriações e ressignificações em perspectiva histórica.

Parece importante destacar que, ao longo dos últimos anos, alguns balanços historiográficos, muitos dos quais bastante competentes, já foram realizados (QUIJADA, 1998; BRANDALISE, 2008; 2013; AILLÓN SORÍA, 2009; FARRET \& PINTO, 2011). Com raras exceções, as abordagens ainda seguem pautadas especialmente pela perspectiva de Ardao, como se pode perceber, por exemplo, nos artigos da argentina Mónica Quijada (1998) e dos brasileiros Rafael Leporace Farret e Simone Rodrigues Pinto (2011) que, mesmo contextualizando na análise a questão do panlatinismo e os interesses imperiais franceses sob Napoleão III, se afiançam, sem grandes questionamentos, à primazia hispano-americana na utilização do conceito, confiando especialmente no pioneirismo de 
Torres Caicedo. Ambos os textos, além disso, embora mencionem a presença norteamericana na América Central, não se aprofundam de forma efetiva sobre a questão.

Dois artigos, escritos pela brasileira Carla Brandalise (2013) e pela mexicana Esther Aillón Soría (2009), merecem também destaque nesse quadro mais geral sobre a formulação do conceito de "América Latina". Além de se constituírem como bons balanços sobre o tema, demonstram de maneira bastante coerente a questão da circulação das ideias entre as duas margens do Atlântico, apontando para a diversidade dos significados da denominação a partir dos múltiplos interesses de seus interlocutores hispano-americanos ou europeus. Entretanto, assim como os citados textos de Quijada (1998) e Farret e Rodrigues Pinto (2011), os trabalhos de Brandalise e Aillón Soría, a despeito dos seus destacados méritos, também não se detém de maneira mais aprofundada sobre as questões associadas à América Central que contribuíram, na década de 1850, para a formulação do substantivo composto "América Latina". Todos esses balanços ignoram ainda a importância do jornalista francês Felix Belly, autor que, como este artigo tentará demonstrar, apresentou uma contribuição relevante para as discussões em torno da "latinidade" da América de colonização ibérica.

Sobre a questão da importância geopolítica da América Central no processo de elaboração do conceito de "América Latina", merecem destaque os trabalhos bastantes instigantes e muito bem documentados de dois historiadores norte-americanos. Em primeiro lugar, Aims McGuinness (2003; 2008), que associa de maneira pertinente as primeiras utilizações da expressão "América Latina" à "corrida do ouro" na Califórnia, iniciada em 1848, e à presença maciça dos norte-americanos no Panamá nesse contexto. Da mesma forma, o excelente artigo de Michael Gobat (2013) que, alicerçado sobre uma perspectiva transnacional, constrói uma reflexão sobre a elaboração do conceito, enfatizando as associações entre a ideia de uma "raça latina" e a construção de um discurso anti-imperial nas Américas. Em um texto que dá ao istmo centro-americano seu devido destaque, Gobat também é um dos raros trabalhos que menciona, mesmo que seja em apenas um parágrafo, o francês Felix Belly. 
De qualquer modo, mesmo com tantos trabalhos escritos sobre o tema, as perspectivas ainda matriciais de Phelan e Ardao seguem guiando os debates. Embora seja menos popular que a visão defendida por Ardao, a tese de Phelan sobre a imposição externa, baseada em interesses geopolíticos internacionais, do conceito de "América Latina" ainda ecoa na historiografia, embora com outras roupagens. Um exemplo é o artigo "O Brasil e a ideia de 'América Latina' em perspectiva histórica”, do historiador inglês Leslie Bethell, publicado em 2009, que se posiciona dentro desse escopo diante de duas questões bastante espinhosas: a validade da utilização do conceito e a presença do Brasil na América Latina.

De acordo com Bethell, o Brasil nunca se enxergou como América Latina e, ao mesmo tempo, jamais foi visto pelos hispano-americanos como tal. Nesse sentido, a inserção do país de língua portuguesa no quadro latino-americano teria sido, em sua interpretação, resultado dos interesses geopolíticos de classificação dos norte-americanos a partir das décadas de 1920 e 1930 e, mais precisamente, nos contextos da Segunda Guerra Mundial e da Guerra Fria.

Enfaticamente, o historiador inglês conclui seu texto da seguinte maneira: “É chegada a hora de o mundo parar de considerar o Brasil como parte daquilo que, na segunda metade do século XX, foi chamado de América Latina, um conceito que seguramente perdeu a utilidade que talvez tenha tido alguma vez" (BETHELL, 2009, p. 314). Em uma só tacada, Bethell exclui definitivamente a possibilidade de o Brasil fazer parte da América Latina e questiona a própria utilização do conceito.

Sob uma ótica diversa da construída pelo autor inglês, o historiador mexicano Maurício Tenório Trillo, em um texto bastante instigante no qual discute a validade ou não da designação "América Latina”, apresenta as contradições tanto no processo de formulação da nomenclatura como na própria presença do Brasil nessa unidade identitária. Ao contrário de Bethell, Tenório entende que, a despeito de todos os problemas que a definição carregaria, entre os quais a própria origem imperial francesa, a concepção de uma "América Latina" poderia abrir diversas possibilidades ao historiador, a começar por ampliar os horizontes dos estudiosos ao partir de uma premissa 
que ultrapassaria, logo de início, a lógica da história nacional. Nas palavras do autor: "sua natureza mais-do-que-nacional pode trazer à vida conexões e interações históricas que são inalcançáveis por meio de meras histórias nacionais" (TENORIO TRILLO, 2012, p. 260).

Dialogando também com Leslie Bethell, o historiador brasileiro Fábio Luís Barbosa dos Santos, em um sentido ainda diverso, localiza a vitalidade e a necessidade da utilização do conceito no âmbito da política externa em um contexto em que o contraponto da região permaneceria sendo os Estados Unidos. Nas palavras do autor:

\begin{abstract}
Reivindicar a atualidade do conceito de América Latina significa posicionar-se criticamente em relação às políticas que reafirmam uma inserção internacional da região subordinada aos Estados Unidos e que, como decorrência, reforçam a fragmentação continental, como é o caso do "Plan Colombia", do NAFTA já citado, dos Tratados de Livre Comércio assinados por diversos países em anos recentes, entre outros. De forma correspondente, sugerir que a noção de América Latina está ultrapassada, justamente em função de políticas dessa natureza, revela um empenho em transformar uma questão em disputa em um fato consumado, operação característica da ideologia e não do pensamento crítico (SANTOS, 2015, pp. 15).
\end{abstract}

É interessante notar, para além das perspectivas historiográficas particulares adotadas por cada um dos autores, que, contrapostos, o artigo de Bethell e esse último texto de Barbosa dos Santos se configuram, em suas linhas gerais, como paradigmáticos ainda hoje dos debates em torno do conceito de "América Latina" tal como estabelecido na década de 1960 pelas interpretações de Phelan e Ardao. De um lado, a ideia de uma invenção externa, fruto dos desígnios estrangeiros e pouco significativa em sua instrumentalização nos contextos particulares do subcontinente e, de outro, a concepção que valida a formulação local e possui um forte viés anti-imperialista, especialmente em relação aos Estados Unidos, atribuindo grande importância à sua utilização nos discursos intelectuais e políticos da região como forma de afirmação cultural e geopolítica.

Para além dos antagonismos expostos por essas duas visões, tomadas lado a lado, essas perspectivas matriciais não deixam de ser complementares. Em um contexto caracterizado pela circulação das ideias, o conceito de "América Latina" foi e é instrumentalizado de diversas maneiras pelos vários atores que dele se apropriaram. Utilizado pelo imperialismo francês e, 
depois, norte-americano como uma designação geopolítica repleta de interesses, foi também assumido pelos latino-americanos, entre os quais, muitas vezes, os brasileiros, como forma de afirmação identitária nos âmbitos da cultura e da política e em oposição e forma de resistência a adversários internos e externos (AILLÓN SORÍA, 2009, p. 72; BRANDALISE, 2013, pp. 75-76).

Nesse processo de elaboração do conceito, duas questões precisam ser debatidas de forma preferencial. As concepções em torno da existência de uma "raça latina", ideia que mobilizou letrados dos dois lados do Atlântico em meados do século XIX, e a relevância do papel geopolítico da América Central em um contexto de disputas imperiais entre "latinos" e "anglo-saxões".

\section{As "raças latinas" entre o Velho e o Novo Mundo: esboçando o conceito de "América Latina"}

Concebido em meados da década de 1850, o conceito de "América Latina" foi sendo gestado ao menos desde os anos 1830 nas duas margens do Atlântico. Antes de ser apropriado especificamente para descrever as relações entre as diversas regiões do Novo Mundo, teve suas raízes fincadas nos debates existentes desde meados do século XVIII a respeito da variedade das "raças" existentes ao redor do globo.

É importante ressaltar que, no início do século XIX, as discussões identitárias realizadas na Europa começavam, cada vez mais, a se utilizar do conceito de "raça" para a constituição de uma divisão entre os diversos povos do mundo. De acordo com Tzvetan Todorov (2003, p. 121), embora a palavra "raça" tenha sido presumivelmente utilizada pela primeira vez na França, em 1634, por François Bernier, foi com a Histoire Naturelle, publicada em diversos volumes entre 1749 e 1804, de George-Louis Leclerc, o conde de Buffon (1707-1788), que a discussão sobre a unidade ou diversidade dos seres humanos encontrou uma base erudita para as grandes teorizações do século XIX.

Em Buffon, a despeito da concepção da existência de uma única origem para todos os homens, havia certamente uma clara hierarquização etnocêntrica e, mais especificamente, eurocêntrica entre os povos do mundo, apontando não somente para a existência de uma divisão entre grupos sociais considerados "civilizados" e "bárbaros", mas que ressaltava também a 
superioridade ou inferioridade de determinados grupos populacionais uns em relação aos outros. Para o autor da Histoire Naturelle, três eram os fatores responsáveis por determinar as divergências entre os vários tipos humanos: a cor da pele, a forma e as dimensões do corpo e os costumes (TODOROV, 2003, pp. 121-131; GERBI, 1993, pp. 7-46).

Sobre o discurso racialista europeu da primeira metade do século XIX, duas questões merecem ser destacadas. Em primeiro lugar, embora carregasse aspectos associados a caracteres externos, físicos e fisionômicos dos seres humanos, as práticas culturais e as origens históricas e linguísticas se configuravam também como elementos centrais para a caracterização do conceito de raça no período. Em segundo lugar, além de sua utilização como forma de classificar e hierarquizar os diversos grupos populacionais dispersos ao redor do mundo, essa visão racialista das sociedades humanas também pautou a concepção acerca da própria formação dos vários países europeus.

Na França, já no início do século XIX, uma obra relevante como De l’Allemagne (1810), escrita por Annie-Louise-Germaine Necker, a célebre Madame de Staël (1776-1817), enquanto estava exilada nos Estados alemães por sua oposição ao governo de Napoleão Bonaparte (17991814), se iniciava da seguinte maneira:

Pode-se reportar a origem das principais nações da Europa a três grandes raças diferentes: a raça latina, a raça germânica e a raça eslava. Os italianos, os franceses, os espanhois e os portugueses receberam dos romanos sua civilização e sua linguagem; os alemães, os suiços, os ingleses, os suecos, os dinamarqueses e os holandeses são povos teutônicos; enfim, entre os eslavos, os poloneses e os russos ocupam o primeiro posto (STAËL, 1815, pp. 1-2) ${ }^{4}$.

Madame de Staël dividia, portanto, as "raças europeias" em três grandes ramos: os latinos, os germânicos e os eslavos. Se na visão da letrada, os franceses eram os "mais cultivados" entre as "raças latinas", os ingleses eram os "mais ilustres" entre os germânicos, exercendo, por sua constituição, uma superioridade decidida entre as nações de sua estirpe (STAËL, 1815, pp. 265-266). Note-se que a definição de Madame de Staël sobre as raças europeias se pautava essencialmente em critérios culturais e não em definições fenópticas e

\footnotetext{
${ }^{4}$ Para facilitar o entendimento do texto, as citações publicadas originalmente em língua estrangeira foram traduzidas para este artigo.
} 
fisionômicas. Em sua abordagem, em De l'Allemagne, não eram as características físicas ou biológicas que guiavam sua conceituação, mas aspectos como a língua, as origens históricas e os caracteres comportamentais e psicológicos dos diversos grupos humanos.

Embora as formulações da Madame de Staël permanecessem vivas, mesmo que modo fragmentado, entre os letrados franceses à época da Restauração (1814-1830), algumas visões da autora voltaram a ganhar repercussão durante a década de 1830, especialmente por meio da historiografia romântica de seu país, na qual se destacava certamente a figura de Jules Michelet (1798-1874).

Para os interesses deste texto, valeria a pena um breve comentário sobre uma passagem de Introduction à l'Histoire Universelle (1831), obra escrita por Michelet sob o impacto da Revolução de Julho de 1830 na França. Em seu prefácio, inspirado pelos eventos que havia acabado de presenciar, defendia tese de que a França estava fadada a ser "o piloto da nau da humanidade" (MICHELET, s.d., p. 401). Michelet ia além, afirmando a "latinidade" francesa e o papel de liderança de seu país em relação às nações europeias nascidas dessa mesma cepa:

\footnotetext{
Enquanto a civilização aprisiona o mundo bárbaro sob as garras invencíveis da Inglaterra e da Rússia, a França abraçará a Europa em toda a sua profundidade. Sua íntima união será, não duvidemos disso, com os povos de línguas latinas, com a Itália e a Espanha, essas duas ilhas que somente podem se entender com o mundo moderno por intermédio da França.

Líder dessa grande família, a França renderá ao gênio latino algo da preponderância material que teve na Antiguidade, da supremacia espiritual que obteve na Idade Média. Nos últimos tempos, o acordo de família que unia a França, a Itália e a Espanha, em uma aliança fraterna, era uma imagem vã dessa futura união que deve reaproximá-las em uma comunidade de vontades e pensamentos (MICHELET, s.d., p. 469-471).
}

A França deveria, pois, como se depreende do texto de Michelet, liderar os demais países "latinos" da Europa, nomeadamente a Itália, nessa época ainda não unificada, e a Espanha. Deve-se ressaltar, em primeiro lugar, a posição ambígua que a ideia de "latinidade" adquiria no excerto, funcionando ao mesmo tempo como signo de identidade e alteridade entre França, Itália e Espanha. Por um lado, conceitos como "união" e "fraternidade" denotariam uma identidade entre essas três nações, por outro, as ideias que atribuíam à França o papel de "líder 
dessa grande família" e "intermediária" entre suas "irmãs" e o "mundo moderno" explicitavam uma clara hierarquia em que a "pátria das Luzes" ocuparia o topo.

Fica evidente, dessa maneira, o lugar da França, estabelecido por seus próprios letrados, como o país a liderar e conduzir a "latinidade" europeia na rota da modernidade. Note-se que se para a Madame de Staël, mesmo apontando a superioridade francesa diante dos demais países latinos, a divisão das raças europeias tinha como objetivo central classificar culturalmente os povos do Velho Continente, em Michelet, a "latinidade" configurava-se, acima de tudo, como uma missão de liderança no contexto europeu a ser cumprida pela França.

Como se pode perceber, as "raças" eram definidas, nesse processo de "racialização das categorias culturais" (QUIJADA, 1998), a partir de critérios que iam além de aspectos meramente físicos ou biológicos, mas relacionavam-se, de maneira bastante destacada, a práticas, costumes e características estabelecidos historicamente. Com base nesses argumentos, foram construídas as linhas gerais que passaram a definir não somente os "latinos", mas também um grupo privilegiado dentro da "raça teutônica", os "anglo-saxões" 5 . No discurso intelectual existente, em meados do século XIX, enquanto os latinos seriam os herdeiros da Roma Antiga, falantes de línguas originárias do latim, católicos e tendentes ao centralismo preferencialmente monárquico, os anglo-saxões teriam o legado de um passado teutônico, seriam falantes de línguas germânicas, protestantes e mais propícios aos regimes parlamentares e representativos.

Consolidando-se na Europa, as discussões racialistas também circularam nas Américas ao longo do século XIX, contribuindo de maneira efetiva para a construção das identidades locais. Destacou-se, nesse processo, o francês Michel Chevalier, personagem central para a formulação do conceito de "América Latina" no século XIX (SANTOS JUNIOR, 2019).

Michel Chevalier (1806-1879) é frequentemente apontado, se não como o inventor do conceito de "América Latina", como possivelmente o primeiro autor a ter afirmado a existência de uma América de "raça latina" em suas Lettres sur l'Amérique du Nord (1836), obra em dois volumes, resultante da viagem que realizou, entre 1833 e 1835, às Américas (CHEVALIER,

\footnotetext{
${ }^{5}$ Por uma questão de recorte, não serão discutidas, neste artigo, as origens da ideia de "raça anglo-saxônica". Para compreender as especificidades da construção dessa identidade específica entre os britânicos e os norteamericanos, ver JUNQUEIRA (2015, pp. 141-153).
} 
1836). Engenheiro especialista em Minas, formado pela Escola Politécnica de Paris e saintsimoniano durante sua juventude ${ }^{6}$, Chevalier foi enviado em missão oficial aos Estados Unidos, no contexto da chamada Monarquia de Julho (1830-1848), com o objetivo de analisar o sistema de comunicações e as vias públicas naquele país. Aproveitando sua viagem ao Novo Mundo, esteve ainda no México e em Cuba, regiões sobre as quais também escreveu, construindo comparações entre os "latinos" que viviam nesses países e os "anglo-saxões" da federação norte-americana ${ }^{7}$.

A referência à América de colonização ibérica como "latina" surgia nas Lettres sur l'Amérique du Nord, de Michel Chevalier em dois momentos, na introdução e na última carta de seu relato sobre os Estados Unidos. As primeiras considerações do livro de Chevalier destacavam o caráter estratégico do Extremo Oriente, em especial a China, para o comércio e a geopolítica europeia de sua época. Nesse sentido, defendia a importância de se facilitarem os contatos com tais regiões, particularmente por meio da construção de canais interoceânicos em Suez, no Egito, e no Panamá, na América Central. Preocupado com a expansão britânica e a ascensão da Rússia, o engenheiro saint-simoniano defendia um posicionamento mais incisivo da França nesse processo.

Ecoando os textos da Madame de Staël e de Michelet, Chevalier concebia também a divisão das populações europeias em três raças: os latinos, os germânicos e os eslavos. Em sua argumentação, advogava ainda a liderança francesa sobre os povos do ramo latino. Entretanto, indo além das concepções de Michelet, o autor das Lettres sur l'Amérique du Nord ampliava

\footnotetext{
${ }^{6}$ Em termos político-ideológicos, Michel Chevalier foi, durante sua juventude, um ardoroso saint-simoniano, ou seja, seguidor das ideias de Claude-Henri de Rouvroy, o conde de Saint-Simon (1760-1825). Resultado de um conjunto complexo de concepções e premissas, essa doutrina, bastante difundida na França na primeira metade do século XIX, tinha como eixos unificadores as concepções de divisão da sociedade entre setores produtivos e ociosos, em que estes últimos atuavam como parasitas e espoliadores dos demais, e a visão de que a indústria e o trabalho, de modo geral, devem se constituir como os elementos centrais da atividade humana. Seu lema, síntese das concepções expostas acima, era "à chacun selon sa capacité, et à chaque capacité selon ses ouvres [a cada um segundo sua capacidade, e a cada capacidade segundo suas obras"]. Os saint-simonianos defendiam fortemente grandes projetos de infraestrutura como a construção de canais e estradas de ferro, além de exaltarem planos de colonização extra-europeia como o de intervenção sobre a Argélia a partir de 1830 (PICON, 2002). Discuti a presença das ideias saint-simonianas em Michel Chevalier em SANTOS JUNIOR (2016)

${ }^{7}$ Diferentemente do que ocorreu, entretanto, com seus textos sobre os Estados Unidos, as "cartas" escritas sobre México e Cuba nunca foram reunidas em livro, podendo ser encontradas apenas na imprensa coeva, principalmente na Revue des Deux Mondes e no Journal des Dèbats (SANTOS JUNIOR, 2019).
} 
os domínios da "latinidade", caracterizando não somente a Itália e a Espanha como países de "raça latina", mas também as regiões colonizadas por espanhois e portugueses no Novo Mundo como herdeiras dos caracteres essenciais de suas metrópoles (SANTOS JUNIOR, 2016, pp. 335$357)$.

$\mathrm{Na}$ concepção do viajante francês, para além dos eslavos, estabelecidos mais recentemente no Velho Continente, a civilização europeia procedia essencialmente de duas formações sociais primitivas, os romanos e os povos germânicos, que inicialmente originaram "duas Europas", uma "latina" e outra "teutônica": a primeira compreendida pelos povos do sul e a segunda, pelos do norte. A primeira, católica e a segunda, protestante; uma delas teria seus idiomas derivados do latim e outra, suas línguas de origem germânica. A mesma estrutura, segundo ele, teria se desenvolvido entre os povos da América: "Os dois ramos, latino e germânico, se reproduziram no Novo Mundo. A América do Sul é, como a Europa Meridional, católica e latina. A América do Norte pertence a uma população protestante e anglo-saxônica" (CHEVALIER, 1836, vol. I, p. X).

A identidade "latina" dos franceses possuía, nas Lettres sur l'Amérique du Nord, assim como na já citada obra de Michelet, feições claramente hierárquicas que posicionavam a França à cabeça dessa "família". Nas palavras de Chevalier, como a "sumidade do grupo latino; sua protetora" (CHEVALIER, 1836, vol. I, p. XII). A liderança francesa em relação aos povos latinos não somente da Europa, mas também da América se constituiria, conforme o autor, como a grande missão a ser exercida por seus políticos, letrados e mercadores, nos anos que se seguissem. Em sua visão, "a França me parece chamada a exercer um benevolente e fecundo mecenato sobre os povos da América do Sul, que estão ainda longe de se bastarem a si mesmos" (CHEVALIER, 1836, vol. I, p. XIII).

Entretanto, se os povos sul-americanos "não se bastavam a si mesmos", a situação francesa, mesmo quando se arrogava um papel de liderança dos "povos latinos" não se apresentava também como minimamente confortável no contexto geopolítico internacional. Chevalier afirmava que, embora os latinos houvessem exercido, por muito tempo, sua hegemonia sobre os povos ocidentais, esse papel vinha sendo ocupado no início do século XIX pelas sociedades de origem teutônica, mais precisamente anglo-saxônica, não somente na 
Europa, mas também por seus descendentes no Novo Mundo. No caso das Américas, apontava para a rápida ascensão dos Estados Unidos, república que, em algumas décadas de existência, já demonstrava indícios de sua força econômica e de seu caráter expansionista.

Na visão do autor, a tendência era que não somente essa preeminência anglo-saxônica na Europa e nas Américas se mantivesse, mas que inclusive se ampliasse. A despeito disso, entendia que as inovações trazidas por esses povos, em particular por ingleses e norteamericanos, longe de serem recusadas pelos latinos, deveriam, em oposição, ser incorporadas em seu desenvolvimento, preservando-se, entretanto, os caracteres gerais de sua própria "raça".

O que estava em jogo, conforme se pode depreender dos escritos de Michel Chevalier, era a capacidade ou não dos franceses de liderarem os povos "latinos" das duas margens do Atlântico. Em sua perspectiva, ou a França assumiria o papel de liderar essas nações na rota da "civilização" e do "progresso" universais, ou paulatinamente perderia espaço em um mundo dominado por anglo-saxões e eslavos. Tratava-se, nesse sentido, de ocupar o papel de principal potência "latina" do mundo.

É importante destacar, nesse contexto, que a possibilidade de liderança francesa sobre os povos da América meridional apontava para uma multiplicidade de significados. Em primeiro lugar, resultaria na influência geopolítica francesa sobre uma parte considerável do globo, em termos territoriais e de importância,. Posteriormente, combateria a pretensa e possível hegemonia dos anglo-saxões da Europa e das Américas sobre seus rivais latinos dos dois lados do Atlântico. Por fim, exerceria seu poder sobre uma região estratégica para os projetos de interligação entre o Ocidente e o Oriente por meio da construção de um canal interoceânico na América Central, preferencialmente no Panamá.

Em suma, parece importante destacar que, desde a publicação das Lettres sur l'Amérique $d u$ Nord, de Michel Chevalier, em 1836, as concepções relacionadas à "latinidade" da América de colonização ibérica se vincularam frequentemente, muitas vezes de maneira intrínseca, em boa parte do século XIX, a ideias relacionadas às possibilidades econômicas abertas especificamente pelas características geográficas e geopolíticas da América Central.

A "latinidade" se apresentava, nesse sentido, como uma missão a ser cumprida pelos franceses, considerados os candidatos naturais a conduzirem o processo de construção de um 
canal interoceânico no istmo centro-americano, preferencialmente no Panamá ou na Nicarágua, que responderia pela sonhada interligação entre os oceanos Atlântico e Pacífico. Entretanto, como já previa Chevalier, em seus escritos da década de 1830, a ascensão dos anglo-saxões da América do Norte adicionou novos elementos a essas disputas envolvendo as regiões que haviam sido colonizadas anteriormente pelos países ibéricos.

\section{Os arautos da unidade "latina": $o$ istmo centro-americano e a ameaça norte-americana}

Conforme destacado no início deste artigo, desde as independências em relação às metrópoles ibéricas, as identidades vivenciaram um contexto de transformação e reelaboração nas Américas. O rompimento dos laços coloniais e o estabelecimento de novos vínculos provinciais, nacionais e continentais resultaram, desde então, em outras concepções sobre o “ser americano" (PRADO; PELLEGRINO, 2014, pp. 87-88).

Para além da formação das novas nacionalidades, uma perpectiva continental já podia ser apreendida em líderes dos processos emancipatórios como Simón Bolívar e Francisco de Miranda que afirmavam, por exemplo, uma identidade essencialmente hispano-americana, antiespanhola e da qual o Brasil certamente não fazia parte. Como deixavam entrever, a partir de então, os discursos políticos e intelectuais produzidos ao longo do século XIX, "América", “Colômbia”, "Hispanoamérica”, “América do Sul”, “América Meridional” e, claro, "América Latina”, entre outros, foram alguns dos nomes recebidos por essa comunidade identitária. Inicialmente, como forma de se posicionar contra a metrópole espanhola nas lutas pela independência e, em um segundo momento, de afirmar sua autonomia em um continente habitado pelos Estados Unidos, um vizinho tão sedutor quanto ameaçador para os letrados hispano-americanas (GRANADOS GARCÍA, 2004, pp. 39-48).

Sobre essa questão, Aimer Granados García concebe, ao analisar os primeiros congressos continentais hispano-americanos ocorridos em meados do século XIX, uma primeira grande transformação em torno da nomenclatura do subcontinente na retórica intelectual e política da região. Se nos debates que se estabeleceram no Congresso do Panamá (1826) predominava, por exemplo, a conceituação “América”, nos encontros posteriores em Lima, no 
Peru, (1848 e 1865) e em Santiago do Chile (1856) ganhava força a designação "Hispanoamérica". É possível afirmar, segundo a interpretação de Granados García de que enquanto na primeira assembleia, sentia-se ainda o impacto das guerras de independência e a busca por afirmação continental diante da Europa, particularmente da Espanha, nas reuniões seguintes, os perigos que rondavam a região não vinham somente do outro lado do Atlântico, mas também do norte de seu próprio continente (GRANADOS GARCÍA, 2004, pp. 49-50).

Importante destacar aqui que o surgimento do conceito de "América Latina" ou "Latinoamérica", a partir da década de 1850, não substituiu pura e simplesmente, como se pode perceber na análise sobre os congressos subcontinentais, as denominações "América Hispânica" ou "Hispanoamérica". Mais que isso, embora, muitas vezes, competissem como denominações que visavam definir uma parcela específica do Novo Mundo, uma delas vinculada às "origens espanholas" e outra associada às pretensões e à influência francesa, ambas conviveram frequentemente de maneira pacífica e, em alguns momentos, foram utilizadas de maneira indistinta e intercambiável por diversos autores dos séculos XIX e XX, especialmente como contraposição identitária aos Estados Unidos (BEIRED, 2014, pp. 631-654).

Como se pode perceber na retórica intelectual e política hispano-americana, a república estadunidense se afigurava, em meados do século XIX, para esses países, em diversas situações, como um vizinho bastante incômodo. Uma série de eventos contribuíram para que começassem a se construir, por parte de setores letrados do subcontinente, visões negativas sobre os Estados Unidos.

É possível dizer que a inflexão na direção desse movimento tenha suas raízes fincadas no processo de anexação do Texas ao território estadunidense, em 1845, e, posteriormente, na guerra entre esse país e o México, ocorrida entre 1846 e 1848, que resultou, para os mexicanos, na perda de quase metade do seu território e em sua incorporação pela expansionista república vizinha (SCHOULTZ, 2000, pp. 33-58; FERES JUNIOR, 2005, pp. 56-71). Entretanto, se na década de 1840, foram nas tensões entre esses dois países limítrofes que se concentraram o foco dos confrontos diplomáticos e bélicos dos Estados Unidos, no decênio seguinte, o eixo dessa política externa agressiva alterou sua direção para a América Central, região também bastante 
estratégica não somente para os norte-americanos, mas para outros países com ambições imperiais como, por exemplo, a Grã-Bretenha e a França.

Para os Estados Unidos, a América Central constituiu-se como um espaço especialmente relevante, principalmente após a anexação da Califórnia e a descoberta de ouro nesse local em 1848. Ainda sem contar com uma potente rede de transportes ligando o Atlântico e o Pacífico em seu próprio território e com a forte presença das populações indígenas no interior de seus agora extensos domínios, os norte-americanos se utilizavam, como vias preferenciais, para alcançar as regiões de sua costa oeste, essencialmente as rotas proporcionadas pelos istmos do Panamá, à época pertencente à Nova Granada (atual Colômbia), da Nicarágua, e de Tehuantepec, no México (MCGUINNESS, 2008).

A presença anglo-saxônica, especialmente nesse período, na vida cultural, social e econômica do istmo se constituiu, portanto, como algo constante. Nesse novo contexto, o fluxo de estrangeiros e, de modo mais evidente, estadunidenses, especialmente no Panamá, tornou-se cada vez mais intenso e conflituoso. O estabelecimento dessa situação resultou, consequentemente, em diversas transformações que perpassavam desde as relações internacionais do continente até o cotidiano das populações centro-americanas.

Em termos geopolíticos, pode ser apontada como uma evidência importante do deslocamento do interesse norte-americano na direção da América Central, a assinatura, em 1850, do Tratado Clayton-Buwler, entre os Estados Unidos e a Inglaterra, em que os dois países se comprometiam a não construir qualquer passagem interoceânica sem a anuência do outro interessado e, no caso de qualquer empreendimento nesse sentido, definiam sua livre utilização por as ambas as nações (WADDELL, 2001, p. 263). Ademais, a construção, entre 1850 e 1855, de uma estrada de ferro interoceânica, El Ferrocarril de Panamá, pela Panama Railroad Company de Nova York, impactou profundamente a vida da população panamenha e modificou fortemente as relações econômicas, sociais e raciais na região (McGUINNESS, 2003, 88-90).

Embora vistas, pelas elites locais, em um primeiro momento, como um meio de transformar o Panamá em uma espécie de coração comercial do mundo, as novas relações econômicas e a intensa onda imigratória em direção ao istmo resultante da construção da ferrovia interocêanica e da corrida do ouro californiana representaram, em outro sentido, a 
constituição de um ambiente de grande tensão entre panamenhos e estrangeiros, principalmente norte-americanos, provocando conflitos, muitas vezes perpassados pela questão racial.

É importante destacar ainda, como contraponto, que a Nova Granada passava desde fins da década de 1840 por marcadas transformações políticas que expunham ainda mais as contradições na região. Se, por um lado, com a ascensão do liberal José Hilário López à presidência do país, em 1849, havia sido proclamada, na futura Colômbia, a igualdade entre todos os cidadãos do sexo masculino com a promulgação do sufrágio universal estendido a todos os homens neogranadinos, por outro, o tratamento diferenciado garantido no istmo aos cidadãos norte-americanos, frequentemente desrespeitosos às leis do país, evidenciava privilégios e a ausência de controle do Estado sobre os atos dos adventícios (McGUINNESS, 2003, pp. 93-97).

No Panamá, um evento simbólico desse quadro de rivalidades na América Central talvez seja o Motim de 15 de abril de 1856, também conhecido na historiografia como "El incidente de la tajada de sandía" ["O incidente do pedaço de melancia"], quando a recusa de um norteamericano em pagar por um pedaço de melancia ao vendedor de rua José Manuel Luna provocou um conflito urbano generalizado no bairro de La Ciénaga, na Cidade do Panamá, evidenciando tensões e antagonismos sociais e raciais latentes nesse contexto (McGUINNESS, 2003, pp. 91-97).

O intenso afluxo de norte-americanos na América Central durante esse período provocou ainda o surgimento de um outro fenômeno na região: o chamado filibusteirismo. Resultado direto da mitologia do Destino Manifesto norte-americano ${ }^{8}$, esse movimento alcançou seu auge entre as décadas de 1840 e 1860 e marcou profundamente a história dos países centro-americanos e dos territórios antilhanos em meados do século XIX.

De acordo com Frederic Rosengarten Jr., os filibusteiros, cuja nomenclatura remontava aos piratas do período colonial, eram, em geral, homens brancos em busca de riqueza e poder que se dedicavam a empreender expedições e ataques bélicos não necessariamente autorizados,

${ }^{8}$ Mary Anne Junqueira define o Destino Manifesto como uma "concepção nacionalista que se apoiava na idéia de Direito Natural, concedido pela divina providência àquele país, de tomar para si toda a parte continental da América do Norte" (JUNQUEIRA, 2018, p. 69). 
mas frequentemente tolerados e silenciosamente apoiados pelo governo dos Estados Unidos a essas regiões. Seus objetivos eram essencialmente conquistar novos espaços para os norteamericanos e principalmente obter ganhos materiais com os butins (ROSENGARTEN JR., 2002, p. 33).

O mais famoso entre os filibusteiros foi o mercenário William Walker, que, em outubro de 1855, lutando na Nicarágua ao lado do Partido Liberal contra os conservadores, tomou o poder naquele país, proclamando-se presidente da república em julho de 1856 com a complacência do governo dos Estados Unidos. Parece importante ressaltar, mais uma vez, que a Nicarágua se constituía como uma das rotas preferenciais para o acesso à Califórnia, o que resultava também nessa região em uma presença bastante agressiva dos norte-americanos.

A situação política nicaraguense somada às tensões existentes no Panamá provocaram uma série de reações dos letrados hispano-americanos do período, dentre os quais de alguns que viviam desterrados no Velho Mundo (ESTRADE, 1998, pp. 179-188). Entre aqueles que se posicionaram contra a forma como os interesses norte-americanos vinham se fazendo sentir na América Central, estava o neogranadino José Maria Torres Caicedo (1830-1889), apontado por Arturo Ardao, como o inventor do conceito de "América Latina".

Torres Caicedo atuou de maneira muito incisiva no periodismo neogranadino entre 1847 e 1850, quando, após ser baleado por motivos políticos migrou para Paris, estabelecendo-se também, nos anos seguintes, por breves períodos em Londres e Nova York. Construindo, ao longo dos anos, sólida carreira diplomática, especialmente na Europa, publicou diversas obras no exterior que transitavam entre a poesia, a crítica literária e a política, enfatizando, em seus textos, frequentemente os temas hispano-americanos (ARDAO, 1980, pp. 74-75). Em meados da década de 1850, começou a contribuir regularmente com o periódico parisiense publicado em língua espanhola El correo de ultramar (1842-1886), do qual se tornou posteriormente redator. Essa publicação foi utilizada por Torres Caicedo para veicular o poema "Las dos Américas", datado de 26 de setembro de 1856, mas dado a ler somente na edição do impresso do dia 15 de fevereiro de 1857.

Celebrizada pela análise de Arturo Ardao, a estrofe abaixo, entendida pelo autor uruguaio como a primeira vez em que teria sido pronunciado na retórica intelectual, tanto na 
Europa como na América, o conceito de "América Latina", contrapunha diretamente a região às populações da "sajona raza", afirmando que apenas a união entre os diversos países hispanoamericanos poderia salvá-los da sanha ameaçadora da república anglo-saxônica:

Mais isolados se encontram, desunidos,

Esses povos nascidos para aliar-se:

A união é seu dever, sua lei amar-se: Igual origem têm e missão; A raça da América Latina, A frente tem a saxônica raça. Inimiga mortal que já ameaça Sua liberdade destruir e seu pendão (TORRES CAICEDO apud ARDAO, 1980, p. 182).

Além dessa estrofe mais célebre, o extenso poema de Torres Caicedo se refere diretamente, em alguns de seus versos menos conhecidos, à situação da América Central ameaçada pela ação dos norte-americanos na região. Cita nominalmente, por exemplo, a intervenção filibusteira de William Walker na Nicarágua:

Em seu amplo pavilhão [dos Estados Unidos] estrelas faltam,

Requer seu comércio outras regiões;

Mas tremulam no Sul livres pendões
- Que caiam! Diz a potente União.
A América Central é invadida,
O istmo sem cessar ameaçado,
E Walker, o pirata, é apoiado
Pela do Norte, pérfida nação!
O seio da América valente
já rasgam seus novos opressores;
Hoje sofre a Nicarágua os horrores
De uma rude e sangrenta escravidão:
Corta os campos o audaz pirata,
Põe fogo às vilas e cidades;
E aprova seus delitos e maldades
Sua pátria, terra outrora de virtude!

Para Torres Caicedo, portanto, a união dos americanos de "raça latina" seria necessária como forma de se contrapor às pretensões norte-americanas na América Central representadas 
de maneira evidente pela atuação de Walker na região e pela postura dos Estados Unidos diante dos acontecimentos no istmo.

Foram também os eventos ocorridos na Nicarágua e no Panamá, que levaram o chileno Francisco Bilbao a se utilizar dos termos "raza latinoamericana" e "América latina" na conferência "Iniciativa de América: idea de un congreso federal de las repúblicas", lida em Paris, no dia 22 de junho de 1856. Sobre a utilização do termo "América latina" na proclamação de Bilbao, parece interessante mencionar que surgia em um contexto no qual o autor chileno explicitava uma visão utópica acerca unidade continental. Não se referia somente, em seu discurso, a uma América "latina", mas também "saxônica" e "indígena", marcada pela união, pela construção da cidadania e do republicanismo e pela recusa de valores hierárquicos de inspiração medieval:

Mas a América vive, a América latina, saxônica e indígena protesta, e se encarrega de representar a causa do homem, de renovar a fé do coração, de produzir, enfim, não repetições mais ou menos teatrais da Idade Média com a hierarquia civil da nobreza, mas a ação perpétua do cidadão, a criação da justiça viva nos campos da República (BILBAO, 1941, p. 146).

Texto bastante curioso, "La iniciativa de América" fazia referências especificamente aos acontecimentos que se seguiram à vitória dos Estados Unidos sobre o México em 1848 e àqueles que vinham ocorrendo na América Central desde meados da década de 1850. O caráter anti-norte-americano de seu discurso ficava evidente, entre outras coisas, pela mobilização da imagem de William Walker como uma espécie de personificação dos próprios Estados Unidos. Segundo ele, "Walker é a invasão. Walker é a conquista. Walker são os Estados Unidos" (BILBAO, 1941, pp. 154-155).

Defensor de ideias consideradas à época como radicais, em obras como, por exemplo, Sociabilidad Chilena (1844), que lhe renderam alguns períodos de exílio na Europa, Bilbao, em sentido próximo ao de Torres Caicedo, afirmava que, aos poucos, a América de colonização espanhola estava sendo incorporada pelos norte-americanos. Há no texto de "Iniciativa de América" uma questão que merece ser destacada: a afirmação de que Estados Unidos e Rússia 
se constituiam, à época, como as duas grandes ameaças imperiais do período. Nas palavras de Bilbao:

\begin{abstract}
Vemos impérios que pretendem renovar a velha ideia da dominação do globo. O Império Russo e os Estados Unidos, potências ambas colocadas nas extremidades geográficas, assim como o estão nas extremidades da política, aspiram, um por estender a servidão russa com a máscara do Paneslavismo, e o outro a dominação do individualismo Yankee. A Rússia está muito longe, mas os Estados Unidos estão perto. A Rússia retira suas garras para esperar em emboscada; mas os Estados Unidos as estendem cada dia nessa partida de caça que têm empreendido contra o Sul. Já vemos cair fragmentos da América nas mandíbulas saxônicas da jiboia magnetizadora, que desenvolve seus abraços tortuosos. Ontem o Texas, depois o norte do México e o Pacífico, saúdam o novo amo.

Hoje as guerrilhas avançadas despertam o istmo e vemos no Panamá, essa futura Constantinopla da América, vacilar suspensa, balançar seu destino no abismo e perguntar: serei do Sul, serei do Norte?' (BILBAO, 1941, p. 144-145)
\end{abstract}

Parece importante destacar que a aproximação construída no texto de Bilbao entre Estados Unidos e Rússia, de um lado, e Panamá e Constantinopla, então capital do Império Otomano, de outro, não parece ser gratuita. Naquele momento, a Europa vivenciava os instantes derradeiros da Guerra da Crimeia $(1853-1856)^{10}$. Na associação que pode ser depreendida do discurso do letrado chileno, assim como a decadente soberania turca, enfraquecida em suas divisões internas, estava ameaçada pelo expansionismo da Rússia, a América Central, também fragmentada e fragilizada, vinha sofrendo intervenções cada vez mais diretas dos Estados Unidos.

$\mathrm{Na}$ fala de Bilbao, o paralelo com a cidade mais importante do Império Otomano guardava uma outra ambiguidade, talvez ainda mais sutil. Mesmo em crise e ameaçada pela invasão dos súditos do czar, Constantinopla ainda era, em meados do século XIX, um dos locais mais importantes do mundo. Desde a Antiguidade, capital de seguidos impérios - romano,

\footnotetext{
${ }^{9}$ As representações de Estados Unidos e Rússia na conferência de Bilbao não eram novidades na França da década de 1850. Nomes importantes da intelectualidade francesa dos anos 1830, como Michel Chevalier e Alexis de Tocqueville, apresentavam visões muito parecidas sobre esses dois países, respectivamente em Lettres sur l'Amérique du Nord e A Democracia na América (SANTOS JUNIOR, 2019, pp. 88-90)

${ }^{10}$ A Guerra da Crimeia (1853-1856) resultou das pretensões russas em relação a territórios pertencentes ao então Império Otomano, especialmente à navegação nos estreitos de Bósforo e Dardanelos. A invasão da Rússia à região do Rio Danúbio provocou o conflito entre o império czarista e a coligação formada por Inglaterra, França, Sardenha e os próprios otomanos. A derrota no cerco de Sebastopol, atual Ucrânia, culminou com a derrota russa, formalmente admitida no Tratado de Paris, assinado no ano seguinte.
} 
bizantino e otomano - e centro político e econômico estrategicamente posicionado nas margens orientais do Mar Mediterrâneo. Ao tratar o Panamá como a "futura Constantinopla da América", Bilbao, de maneira ambivalente, não somente explicitava o temor de que o istmo pudesse se submeter a interesses estrangeiros, em referência ao que ocorria naquele momento com a capital otomana, mas também alentava a possibilidade de um destino grandioso para a cobiçada região, compreendida como uma espécie de coração da América Hispânica.

Assim como para a manutenção do Império Otomano seria necessário que se garantisse a sobrevivência de Constantinopla, para a continuidade da existência da "raça latino-americana" seria preciso defender o istmo da ameaça ianque. Os destinos da América seriam decididos, nessa perspectiva, no Panamá. Nas palavras de Bilbao: “o Panamá simboliza a fronteira, a cidadela e o destino de ambas Américas" (BILBAO, 1941, p. 154).

Para sobreviver em meio a essa disputa, o chileno entendia que a única forma de resistir aos Estados Unidos seria a "união" dos vários países hispano-americanos. Segundo ele, “Unidos, o Panamá será o símbolo de nossa força, a sentinela de nosso porvir. Des-Unidos, será o nó górdio cortado pela faca do ianque e que dará [aos Estados Unidos] a posse do império" (BILBAO, 1941, p. 154).

Não eram, entretanto, somente os hispano-americanos que viviam no Velho Continente que se utilizavam da retórica da "latinidade" para se posicionarem frente aos Estados Unidos diante dos eventos que vinham ocorrendo na América Central.

Aims McGuinness destaca, por exemplo, a participação no debate do jurista e político liberal Justo Arosemena, um dos idealizadores da constituição do Estado Federal do Panamá e seu primeiro chefe do poder executivo, em 1855. Embora defendesse o livre comércio na região, posicionava-se fortemente contra a presença agressiva dos norte-americanos no istmo. Em um artigo, publicado no periódico de Bogotá El neogranadino, em julho de 1856, repetindo alguns lugares comuns dos antagonismos identitários existentes nas Américas, contrapunha a "raça latina" à "raça ianque", defendendo que os "povos hispanoamericanos" deveriam formar uma grande confederação que se estendesse do istmo centro-americano ao sul do continente e afirmando que a questão do Panamá não era somente um problema regional ou nacional, mas dizia respeito essencialmente ao "interesse latino-americano" (McGUINNESS, 2003, p. 100-101). 
As ideias relacionadas à "raça latina" ou "latino-americana" e à formulação do conceito de "América Latina" se apresentavam, portanto, na retórica intelectual hispano-americana de meados da década de 1850 como uma resposta aos avanços dos Estados Unidos no istmo centroamericano, especialmente no Panamá e na Nicarágua, funcionando como críticas à voracidade da "raça anglo-saxônica" ou "ianque" e como convocação à união das nações do subcontinente como forma de resistir ao poderoso vizinho. Entretanto, não foram somente os hispanoamericanos que mobilizaram a ideia da "latinidade" das Américas na década de 1850. Diversos autores franceses também participaram desse debate, frequentemente com objetivos bastante diversos daqueles apresentados pelos letrados do Novo Mundo.

\section{Os interesses franceses na América Central e a invenção da "América Latina"}

Por algumas razões, configura-se como impossível construir a história do conceito de "América Latina" apenas com personagens do Novo Mundo. Primeiramente porque a teorização racialista em que se baseia a discussão, a despeito das apropriações originais e utilizações inovadoras feitas nas Américas, tinham nos letrados europeus importantes balizas. Em segundo lugar, porque as ideias e as pessoas circulavam e, nesse sentido, alguns dos hispano-americanos que contribuíram para a cristalização da designação estavam na Europa no período em que o termo começou a se estabelecer (ESTRADE, 1998). Por fim, porque muitos intelectuais e políticos europeus, especialmente franceses, também demonstravam preocupação com a presença dos Estados Unidos na América Central e se utilizaram da retórica da "latinidade" para problematizar a atuação dos Estados Unidos e defender sua posição geopolítica na América de colonização ibérica.

A defesa de uma presença mais incisiva na América Central já vinha sendo reivindicada pelos franceses há algumas décadas. Conforme ressaltado anteriormente, a construção de um canal no istmo centro-americano com o objetivo de ligar o Atlântico ao Pacífico constituía-se, na França, já na década de 1830, como um projeto encampado pelos saint-simonianos, entre os quais o próprio Michel Chevalier (SANTOS JUNIOR, 2016). Além de se utilizar de uma ideia de "latinidade" para conceber a abertura de uma rota interoceânica sob os auspícios franceses, em 
suas Lettres sur l'Amérique du Nord, em 1836, o engenheiro e professor do Collège de France voltou a publicar sobre o assunto um artigo na Revue des Deux Mondes, em 1844, defendendo, mais uma vez, a importância do empreendimento (CHEVALIER, 1844).

Chevalier não era, entretanto, o único entusiasta célebre da construção de um canal na América Central. Entre seus grandes apoiadores estava nada menos que Louis Napoléon Bonaparte, o futuro imperador da França Napoleão III. Em 1849, quando já era presidente da república, Bonaparte, em um texto publicado na Revue Britannique, revelava uma troca de correspondências que tivera, anos antes, com Francisco Castellón, então ministro plenipotenciário nicaraguense na Europa, posteriormente presidente daquele país. Em seus escritos, exaltava a importância de se edificar uma passagem entre os oceanos Atlântico e Pacífico na Nicarágua (BONAPARTE apud BELLY, 1858, pp. 81-120).

Para os objetivos deste texto, parece importante destacar um personagem ainda um tanto obscuro no debate em torno das primeiras utilizações do conceito de "América Latina", que atuou como um importante mediador entre o governo imperial de Napoleão III e a América Central na defesa da construção de um canal interoceânico na região: o jornalista e negociante francês Felix Belly (1816-1886).

Após atuar por muitos anos na imprensa de seu país, especialmente em Rouen, na Normandia, Belly esteve em Constantinopla, entre 1853 e 1855, cobrindo os assuntos do Império Otomano e, particularmente, a Guerra da Crimeia (1853-1856), para os jornais Constitutionnel e Morning Chronical. Retornando à França após uma passagem por Berlim, onde conheceu o já bastante idoso Alexander von Humboldt, passou a demonstrar interesse pelos assuntos da América Central. Já em 1855, no periódico bonapartista Le pays, publicou dois textos sobre a temática, um discutindo a possibilidade da construção de canais interoceânicos em Suez e no Panamá e outro tratando da invasão de William Walker à Nicarágua (POTVIN, 1889, pp. VXLII),

Interessa aqui, para os objetivos deste artigo, um texto específico de Belly, intitulado "Du conflit anglo-américain et de l'équilibre du Nouveau Monde", publicado em 15 de junho de 1856 na Revue contemporaine. Nele, o jornalista, declarado apoiador de Napoleão III, acusava as pretensões dos Estados Unidos em relação às demais nações do continente 
americano e denunciava a destituição do governo legítimo da Nicarágua pelo aventureiro William Walker. Comparava também o expansionismo norte-americano em relação aos seus vizinhos do sul às intenções russas sobre os territórios pertencentes ao Império Otomano. Afirmava que, assim como a desatenção das potências europeias frente aos avanços do czar terminaram por provocar a Guerra da Crimeia, a tolerância em relação aos desmandos dos Estados Unidos no istmo centro-americano poderia levar também a consequências desagradáveis aos para países do Velho Mundo.

$\mathrm{O}$ alvo de Belly, em seu texto, era a política externa norte-americana, com ênfase à presença dos filibusteiros que, desde o início da década de 1850, vinham atuando na América Central por meio de ataques à região que culminaram com a ascensão ao poder, na Nicarágua, de William Walker, personagem a quem o autor dedicou um grande número de páginas. Para o periodista, da maneira como os fatos vinham ocorrendo, se medidas não fossem tomadas, sequer a América do Sul - do Amazonas ao Prata, passando pelo Brasil - estaria livre da ação filibusteira (BELLY, 1856, pp. 121-155).

Na conclusão de seu texto, Belly recorria, assim como seus contemporâneos hispanoamericanos, à evocação da diferença entre as "raças" do Novo Mundo, descrevendo uma América cindida entre "anglo-americanos" e "latinos", definidos por seus caracteres culturais específicos e por sua atuação em relação aos demais povos do mundo. Nas palavras do jornalista:

\footnotetext{
Duas raças, duas religiões, duas influências essencialmente contrárias e hostis partilham a terra de Colombo. Ao norte, a raça anglo-americana, resultado da cepa puritana, intolerante e ousada, ambiciosa e ativa, ocupa uma região tão vasta como nossa Europa; do Canadá ao México, e do Pacífico ao Atlântico. Ao sul, a raça latina, saída inteiramente da Península espanhola, católica de religião, indolente de costumes, mas apta a seguir todos os impulsos fecundos, se estende sobre um espaço imenso do México ao Cabo Horn (BELLY, 1856, p. 150).
}

Belly, buscando discutir a aparente superioridade dos "anglo-americanos" em relação aos "latinos", atribuía, em grande medida, ao passado colonial a infelicidade destes últimos, afirmando que espanhois e portugueses teriam plantado no Novo Mundo somente a ambição, a cupidez, os favoritismos, a corrupção, a desconfiança popular, a superstição e a intolerância. 
Nas novas nações americanas, essa atuação das metrópoles ibéricas teria resultado em sociedades marcadas pelo desprezo em relação ao trabalho, pelo preconceito de castas, pelo amor aos títulos, pelo despotismo cego e pelas aristocracias vaidosas. Despreparados, sem luzes, sem coesão, sem confiança e sem homens superiores para conduzir o processo de estabelecimento dos novos países após a emancipação em relação às metrópoles ibéricas, o México, a América Central e a América do Sul vivenciavam, em suas palavras, a "anarquia de revoluções periódicas" (BELLY, 1856, p. 151).

Isso significaria, de acordo com o autor, que jamais os "latinos" da América poderiam encontrar a civilização? Na opinião Belly, não. Primeiramente, porque, segundo ele, todas as "raças" seriam passíveis de serem "civilizadas". Além disso, o próprio subcontinente oferecia bons exemplos de desenvolvimento, como o Brasil, o Chile e a Costa Rica. A América de "raça latina" apresentava, em sua visão, um desejo crescente de encontrar a ordem e a liberdade e indicava elementos que possibilitariam sua redenção. Em suas palavras:

\begin{abstract}
A necessidade de ordem está em todo lugar, assim como a de liberdade. Pode-se mesmo dizer que, sob esse aspecto, quase todas as constituições sul-americanas são obras-primas. Os costumes, por outro lado, dessas populações muito pouco conhecidas, bastariam para lhes [fazer] merecer as simpatias dos europeus. Enquanto as seitas mais monstruosas recrutam adeptos aos Estados Unidos e que a multiplicidade das aberrações religiosas turba ali as consciências mais fortes, toda América Latina reconhece o mesmo culto, professa o mesmo dogma e se inclina diante da mesma autoridade espiritual (BELLY, 1856, p. 156).
\end{abstract}

Utilizando-se do conceito de "América Latina" como substantivo composto, na publicação de 15 de junho de 1856, precedendo em mais ou menos uma semana a conferência de Bilbao e em alguns meses o poema de Torres Caicedo, o jornalista Felix Belly idealizava a América de colonização ibérica, por seu pretenso desejo de ordem e liberdade, por seus costumes, seu catolicismo e, principalmente, sua abertura à influência europeia, como o local privilegiado para o estabelecimento político, moral e, especialmente, econômico dos homens do Velho Continente, e particularmente dos franceses. Segundo Belly: "Essa civilização cristã da América central e meridional chama hoje nossa justiça para lhe salvar, ela requer por todas suas vozes o mecenato de nosso direito público; ela reclama também sua entrada no concerto europeu, e a garantia de sua autonomia ameaçada pela invasão" (BELLY, 1856, p. 154). 
O autor concluía seu texto afirmando que a única salvação possível para a "América Latina" seria a intervenção europeia nos assuntos do Novo Mundo: "Essa independência, o momento parece vir decretá-la; essa segurança, a Europa tem o direito de exigir em nome de seus próprios interesses. Ora, é nessa intervenção onipotente que reside para nós, para a América do Sul, mesmo para os Estados Unidos, a verdadeira solução do equilíbrio do Novo Mundo" (BELLY, 1856, p. 155).

Mesmo que apenas como uma provocação, seria possível dizer que Felix Belly foi o primeiro, antes de Bilbao ou Torres Caicedo, a se utilizar do conceito de "América Latina"? É impossível afirmar com certeza, pois novas fontes sempre podem ser encontradas e novas perspectivas sempre podem se fazer valer. Em outro sentido, seria possível afirmar que os autores que se apropriaram da nomenclatura nesse período, como os próprios Bilbao e Torres Caicedo, leram o texto de Belly? É possível, pois, aparentemente, o artigo publicado na Revue Contemporaine causou certa repercussão na Europa e nas Américas (ALLEN, 1957, p. 46). Além disso, Bilbao, como já demonstrou, por exemplo, Maria Ligia Prado (2010), era um leitor da imprensa francesa, em particular da Revue des Deux Mondes. Como estava em Paris, no momento da publicação do artigo de Belly, é possível que tenha tido contato com o texto do jornalista partidário de Napoleão III.

Entretanto, é importante ponderar que as evidências documentais não são conclusivas a esse respeito. No limite, as respostas a essas perguntas, em especial à primeira, pouco importam. É relevante, entretanto, notar que a construção dessa designação foi fruto de décadas nas quais as ideias racialistas passaram a circular dos dois lados do Atlântico, sendo que, instigadas pelo avanço dos Estados Unidos, provocaram uma intensa onda de reflexões identitárias tanto entre os hispano-americanos como entre os franceses, oferecendo respostas e utilizações diferentes a contextos e conceitos similares. Nem cópia pura e simples de um termo nascido dos interesses panlatinistas franceses, nem fruto unicamente do talento original de um poeta hispanoamericano, a denominação "América Latina" foi concebida nas duas margens do Atlântico como resultado de uma reflexão intelectual sobre o expansionismo norte-americano que começava a se evidenciar, sobre a capacidade de defesa dos países ameaçados por esse processo e sobre o papel da América Hispânica e da Europa diante desses eventos. 
Embora de estilos bastante diferentes, os textos de Belly e Bilbao discutem as mesmas temáticas e constroem, curiosamente, as mesmas aproximações, associando, por exemplo, a presença dos estadunidenses no istmo centro-americano à dos russos nos domínios turcootomanos. Não bastasse a construção dessas relações, há, no artigo de Belly, mesmo que como uma citação indireta, a comparação de uma região centro-americana, mesmo que em outro viés, à cidade de Constantinopla. Citando um texto antigo, atribuído ao "príncipe", como era conhecido antes de chegar ao poder Louis Napoléon Bonaparte, Belly destacava, em uma nota de rodapé, um paralelo entre a capital otomana e a Nicarágua:

Eis o que escrevia, há dez anos, sobre essa questão o príncipe que preside hoje os destinos da França: "Existe no Novo Mundo, um país tão admiravelmente situado quanto Constantinopla: é o Estado da Nicarágua. Assim como Constantinopla é o centro do Velho Mundo, a cidade de León, ou logo Masaya, é o centro do Novo" (BELLY, 1856, P. 155).

No entanto, da mesma forma que as temáticas e comparações apontam para similaridades entre os dois publicistas, as conclusões dos dois textos são essencialmente diferentes. Se para Belly apenas a intervenção europeia na América poderia evitar o domínio norte-americano sobre todo o continente, para Bilbao, seria a união entre os hispano-americanos que evitaria essa situação.

Em 1858, Belly viajou à América Central, onde foi recebido pelas autoridades locais para negociar a construção de um canal interoceânico. Embora oficialmente as lideranças bonapartistas negassem a formalidade desses encontros e o caráter oficial das tratativas, o jornalista apresentava-se sempre nos países que visitava com um documento assinado pelo próprio imperador Napoleão III, endossando as possibilidades de convênio (ALLEN, 1957, p. 48). Mesmo tendo conseguido estabelecer acordos de concessão exclusiva para a edificação das rotas ligando o Atlântico ao Pacífico dos governos da Nicarágua e da Costa Rica, o momento desfavorável vivenciado pelos governos centro-americanos no período e a dificuldade em arregimentar financiamento para a empresa fizeram com que Belly abandonasse o projeto no ano seguinte (SCHOULTZ, 2000, p. 180). 
Os interesses geopolíticos franceses em relação à América "latina" permaneceram vivos nos anos que se seguiram, resultando, por exemplo, na participação do governo bonapartista na intervenção ao México, iniciada em 1861 e encerrada de maneira trágica com o fuzilamento do imperador austríaco Maximiliano de Habsburgo, em 1867. Ao defender a presença militar e política da França nos territórios do Novo Mundo colonizados pelos ibéricos, Michel Chevalier, então um dos principais conselheiros de Estado do governo de Napoleão III e possivelmente "o economista preferido do imperador" (HARVEY, 2015, p. 204), utilizava o argumento da "latinidade" dessa porção da América como uma das justificativas para a atuação francesa na região. Em suas palavras:

Há na civilização ocidental ou cristã um ramo bem distinto que se define pela denominação de raças latinas. Ele tem sua sede na França, na Itália, na península hispano-portuguesa e nos países que as nações francesa, italiana, espanhola, portuguesa, povoaram com seus rebentos. Ele é caracterizado pela preponderância numérica ou mesmo pela dominação exclusiva do culto católico. Ele não é todo o catolicismo, mas nele é mais particularmente vigoroso e brilhante. Sem rebaixar ninguém, pode-se dizer que a França é, há muito tempo, a alma desse grupo; não somente a alma, mas o braço. Sem ela, sem sua energia e sua iniciativa, o grupo das nações latinas seria reduzido no mundo a fazer somente uma figura subalterna, e teria, há muito tempo, sido completamente eclipsado. Ela não forma somente a sumidade do grupo latino, ela é sua protetora desde Luís XIV (CHEVALIER, 1862, p. 87).

Derrotados pelos liberais republicanos e expulsos do território mexicano em 1867, os franceses, por intermédio de Michel Chevalier, ainda tentaram uma última cartada na América Central ao assinar um convênio, em 1869, com o ministro dos assuntos estrangeiros da Nicarágua, Tomás Ayon, para a construção de um canal interoceânico naquele país (WALCH, 1975, p. 78). A derrota de Napoleão III e a queda do Segundo Império, no ano seguinte, após o revés sofrido na Batalha de Sedan, episódio decisivo para os rumos da Guerra Franco-Prussiana (1870), praticamente sepultaram a possibilidade de uma política externa mais agressiva dos franceses em relação ao Novo Mundo. Sua preeminência cultural sobre a região não deixou, entretanto, de ser reivindicada dos dois lados do Atlântico e defendida por diversos franceses e francófilos das Américas ao longo dos dois último séculos (AILLÓN SORÍA, 2004, pp. 71-102; ROLLAND, 2005). 
Por outro lado, na retórica ibero-americana, incluindo-se aqui o Brasil, o conceito de “América Latina", utilizado desde meados da década de 1850, cristalizou-se como nomenclatura predominante no continente possivelmente apenas após 1898, no contexto da Guerra Hispanoamericana. Em resposta ao conflito entre Estados Unidos e Espanha, que resultou na vitória norte-americana, na independência tutelada de Cuba e na incorporação de Porto Rico, das Filipinas e de Guan aos domínios estadunidenses, políticos e intelectuais do subcontinente apropriaram-se da denominação como uma bandeira identitária e como forma de resistência, no âmbito do discurso, aos avanços da república do norte (SANTOS JUNIOR, 2016, pp. 215-278). Como discutido anteriormente, embora a validade do conceito venha sendo ainda hoje questionada em diversas situações, é importante destacar sua força e permanência mesmo em tempos permeados pela incompreensão sobre a diversidade e a riqueza de seus significados.

\section{Considerações finais}

Neste artigo, buscou-se contribuir com o debate a respeito do já bastante discutido processo de elaboração do conceito de "América Latina" e sobre seus diversos significados desde sua formulação em meados do século XIX até suas diversas interpretações historiográficas concebidas até hoje. Para além de aderir a matrizes específicas, privilegiou-se apreender esse movimento sob a ótica da circulação de ideias entre as Américas e a Europa, atentando-se sempre às suas apropriações e mutações vivenciadas em contextos específicos.

Nesse sentido, é possível afirmar que se para políticos e intelectuais relevantes do subcontinente, como Francisco Bilbao, José Maria Torres Caicedo ou Júlio Arosemena, apenas a união das repúblicas da região poderia impedir os avanços dos Estados Unidos, para franceses como Michel Chevalier ou Felix Belly, os eventos que vinham ocorrendo no Novo Mundo exigiam certamente a intervenção diplomática, econômica ou militar dos europeus. Se a ideia de "latinidade" denotava para os letrados do Novo Mundo uma alternativa e um artefato de combate político e retórico que, por meio de um discurso identitário, conclamava a defesa e a confederação de povos falantes de uma mesma língua, praticantes de uma mesma religião e ameaçados pelo mesmo inimigo, para setores da intelectualidade francesa vinculados ao 
bonapartismo significava uma forma de fazer valer seus interesses geopolíticos e econômicos em uma região do mundo que parecia estar se tornando monopólio da "raça anglo-saxônica".

Este texto procurou ressaltar a importância das questões relacionadas à América Central, particularmente ao Panamá e à Nicarágua, na formulação do conceito de América Latina na década de 1850. Os franceses que defendiam a construção de um canal no istmo desde os anos 1830, como demonstram os textos de Michel Chevalier, se sentiram ameaçados em seus projetos quando perceberam que a região vinha sendo ocupada de várias formas por seus rivais "anglosaxões", principalmente os Estados Unidos. As questões associadas aos centro-americanos nesse processo, é importante destacar, não estavam relacionadas unicamente aos interesses externos a esses locais, mas se articulavam também a tensões políticas internas a eles, como os motins ocorridos na Cidade do Panamá ou as disputas entre liberais e conservadores que resultaram na intervenção de William Walker na Nicarágua. Tais eventos foram lidos de maneiras diversas por hispano-americanos e europeus, mas geraram um intenso debate que resultou na formulação do conceito de "América Latina".

\section{Referências Bibliográficas}

\section{Fontes}

BELLY, Felix. "Du conflit anglo-américain et de l'équilibre du Nouveau Monde". Revue Contemporaine, Paris, t. XXVI, juin./jul. 1856, pp. 121-155.

Percement de l'Isthme de Panama para le canal de Nicaragua: exposé de la question. Paris: Bureaux de la Direction du Canal, 1858.

L'Isthme américain: notes d'un premier voyage, 1858. Bruxelas: P. Weissembruch, Imprimeur du Roi, 1889.

BILBAO, Francisco. La América en peligro. Evangelio americano. Sociabilidad chilena. Santiago: Edicciones Ercilla, 1941.

CHEVALIER, Michel. Lettres sur l'Amérique de Nord. Paris : Libraire de Charles Gosselin et Cie., 1836, 2 vols.

. "L’Isthme de Panama”. Revue des Deux Mondes, t. 5, 1844, pp. 5-74.

. L'expédition au Méxique. Paris: E. Dentú-Libraire au Palais Royal, 1862. 
MICHELET, Jules. Oeuvres completes de J. Michelet: Précis d'Histoire Moderne/Introduction a l'Histoire Universelle. Paris: Ernest Flammarion Éditeur, s.d.

POTVIN, Charles. "Felix Belly". In: BELLY, Felix. L'Isthme américain: notes d'un premier voyage, 1858. Bruxelas: P. Weissembruch, Imprimeur du Roi, 1889.

STAËL, Annie-Louise-Germaine Necker, Madame de. De l'Allemagne. Paris: Libraire Stéréotype de H. Nicolle; Guyot et Pelafol Libraires, 1815.

\section{Bibliografia}

AILLÓN SORÍA, Esther. "La política cultural de Francia en la génesis y difusión del concepto de L'Amérique Latine", 1860-1930". In: GRANADOS GARCÍA, Aimer e MARICHAL, Carlos (orgs.). Construcción de las identidades latinoamericanas: ensayos de historia intelectual, siglos XIX y XX. México: El Colegio de México, 2004.

ALLEN, Cyril. "Félix Belly: Nicaraguan Canal Promoter". The Hispanic American Historical Review, Vol. 37, No. 1 (Feb., 1957), pp. 46-59.

ANDERSON, Benedict. Comunidades imaginadas: reflexões sobre a origem e a difusão do nacionalismo. São Paulo: Companhia das Letras, 2008.

ARDAO, Arturo. Genesis de la idea y el nombre América Latina. Caracas: Centro de Estudios Latinoamericanos Romulo Gallegos, 1980.

. "La idea de Latinoamérica". Marcha, Montevidéu, n. 1282, 27 de noviembre de 1965.

BEIRED, José Luís Bendicho. "Hispanismo e latinismo no debate intelectual ibero-americano". Varia História, Belo Horizonte, vol. 30, n 54, p.631-654, set/dez 2014.

BETHELL, Leslie. "O Brasil e a ideia de 'América Latina' em perspectiva histórica”. Estudos históricos, Rio de Janeiro, vol. 22, n. 44, 2009, pp. 289-321.

BLOCH, Marc. Apologia da história ou o ofício do historiador. Rio de Janeiro: Jorge Zahar, 2001.

BRANDALISE, Carla. "Ideia e concepção de latinidade nas Américas: a disputa entre as nações". In: ORO, Ari Pedro (org.). Latinidade da América Latina: enfoques socioantropológicos. São Paulo: Hucitec, 2008. 
. "O conceito de América Latina: hispano-americanos e pan-latinidade europeia". Cuadernos del CILHA, vol. 14, n. 2013, pp. 74-106.

ESTRADE, Paul. "Del invento de 'América Latina' en Paris por latinoamericanos (18561889)". In: MAURICE, Jacques e ZIMMERMAN, Marie-Claire (orgs.). Paris y el mundo ibérico e iberoamericano. Paris: Université Paris X-Nanterre, 1998.

FARRET, Rafael Leporace \& PINTO, Simone Rodrigues. "América Latina: da construção do nome à consolidação da ideia". Topoi, vol. 12, n. 23, 2011, pp. 30-42.

FERES JUNIOR, João. A história do conceito de 'Latin América' nos Estados Unidos. Bauru: Edusc, 2005.

FRANCO, Stella Maris Scatena. Viagens e relatos: representações e materialidade nos périplos latino-americanos pela Europa e pelos Estados Unidos no século XIX. São Paulo: Intermeios, 2018.

"Latinos versus Anglo-saxões: projeções identitárias nos relatos de hispanoamericanos pelos Estados Unidos no século XIX". Almanack, Guarulhos, n. 16, p. 39-79, Ago. 2017.

GERBI, Antonello. La disputa del Nuevo Mundo: historia de una polémica, 1750-1900. México: Fondo de Cultura Económica, 1993.

GOBAT, Michael. "The Invention of Latin America: a Transnational History of AntiImperialism, Democracy and Race". The American Historical Review, vol. 118, issue 5, December/2013, pp. 1345-1375.

GRANADOS GARCÍA, Aimer. "Congresos e intelectuales en los inicios de un proyecto y de una conciencia continental latinoamericana, 1826-1860”. In: GRANADOS GARCÍA, Aimer e MARICHAL, Carlos (orgs.). Construcción de las identidades latinoamericanas: ensayos de historia intelectual, siglos XIX y XX. México: El Colegio de México, 2004.

HARVEY, David. Paris: capital da modernidade. São Paulo: Boitempo, 2015.

JASMIN, Marcelo Gantus \& FERES JUNIOR, João (orgs.). História dos conceitos: debates e perspectivas. Rio de Janeiro: Editora PUC-Rio; Loyola; IUPERJ, 2006.

JUNQUEIRA, Mary Anne. Estados Unidos: Estado nacional e narrativa da nação (17761900). 2 ed. São Paulo: Edusp, 2018.

Velas ao mar: U.S. Exploring Expedition (1838-1942), a viagem científica de circumnavegação dos norte-americanos. São Paulo: Intermeios, 2015. 
McGUINNESS, Aims. Path of Empire: Panama and the California Gold Rush. Ithaca: Cornell University Press, 2008.

"Searching for Latin America: race and sovereignty in the Americas in the 1850s". In: APPELBAUM, Nany P.; MACPHERSON, Anne S. e ROSEMBLATT, Karin A. (orgs.). Race and nation in modern Latin America. Chapel Hill: The University of North Carolina Press, 2003.

MIGNOLO, Walter. La idea de América Latina: la herida colonial y la opción decolonial. Barcelona: Editorial Gedisa, 2007.

PHELAN, John Leddy. "El origen de la idea de Latinoamérica (1965)". In: ZEA, Leopoldo (org.). Fuentes de la cultura latinoamericana. Vol. I. México: Fondo de Cultura Económica, 1993.

PICON, Antoine. Les saint-simoniens: raison, imaginaire et utopie. Paris: Belin, 2002.

PRADO, Maria Ligia Coelho. "Identidades latino-americanas". In: AYALA MORA, Enrique e POSADA CARBÓ, Eduardo (org.). Historia general de la América Latina. Vol. VII - Los proyectos nacionales latinoamericanos: sus instrumentos y articulación, 1870-1930. 1. ed. Paris: UNESCO; Editorial Trotta, 2008.

- "Leituras políticas e circulação de idéias entre a França e as Américas: Francisco Bilbao e a Revue des Deux Mondes". In: BEIRED, José Luis Bendicho; CAPELATO, Maria Helena Rolim \& PRADO, Maria Ligia Coelho (orgs.). Intercâmbios políticos e mediações culturais nas Américas. Assis: FCL-Assis-Unesp Publicações; São Paulo: Laboratório de Estudos de História das Américas-FFLCH-USP, 2010.

; PELLEGRINO, Gabriela. História da América Latina. São Paulo: Contexto, 2014.

QUIJADA, Mónica. "Sobre el origen y difusión del nombre América Latina (o una variación heterodoxa en torno de la construcción social de la verdad". Revista de Indias, vol. LVIII, n. 214, 1998, pp. 595-616.

ROJAS MIX, Miguel. "Bilbao y el hallazgo de América Latina: unión continental, socialista y libertária". Cahiers du monde hispanique et luso-brésilien, n. 46, 1986, pp. 35-47.

ROLLAND, Denis. A crise do modelo francés: a França e a América Latina - cultura, política $e$ identidade. Brasília: Editora da UnB, 2005.

ROSENGARTEN JR., Frederic. William Walker y el ocaso do filibusterismo. Tegucigalpa: Guaymuras, 2002. 
SANTOS, Fábio Luís Barbosa dos. "Gênese e atualidade da noção de América Latina: uma reflexão sobre o sentido histórico da integração continental". Faces da História, Assis-SP, v.2, nº 1, p. 06-16, jan.-jun., 2015.

SANTOS JUNIOR, Valdir Donizete dos. Utopias industriais, sonhos imperiais: Michel Chevalier entre latinos e anglo-saxões na Europa e nas Américas (1833-1863). Tese de Doutorado. São Paulo: FFLCH-USP, 2019.

- A trama das ideias: intelectuais, ensaios e construção de identidades na América Latina (1898-1914). São Paulo: Intermeios, 2016.

"A latinidade e as Luzes: a França, o Oriente e o lugar das Américas nas Lettres sur l'Amérique du Nord, de Michel Chevalier (1836)". Dimensões, v. 36, jan.-jun. 2016, p. 335357.

SCHEIDT, Eduardo. "Representações de América no pensamento de Francisco Bilbao". Dimensões, v. 19, p. 27-47, 2007.

SCHOULTZ, Lars. Estados Unidos, poder e submissão: uma história da política norteamericana em relação à América Latina. Bauru: Edusc, 2000.

SOARES, Gabriela Pellegrino. Escrita e edição em fronteiras permeáveis: mediadores culturais na formação da nação e da modernidade na América Latina (século XIX e primeiras décadas do XX). São Paulo: Intermeios, 2017.

TENORIO TRILLO, Maurício. “América Latina: a ideia, mais uma vez”. Intersecções, Rio de Janeiro, vol. 14, n. 2, 2012, pp. 241-267.

TODOROV, Tzvetan. Nosotros y los otros: reflexión sobre la diversidad humana. 3 ed. México: Siglo XXI, 2003.

WADDELL, D. A. G. "A política internacional e a independência da América Latina". In: BETTHELL, Leslie (org.). História da América Latina: da independência a 1870, vol. III. São Paulo: Edusp; Imprensa Oficial; Brasília: Funag, 2001.

WALCH, Jean. Michel Chevalier, économiste saint-simonien. Paris: Vrin, 1975. 